\title{
UPAYA MENINGKATKAN MOTIVASI DAN HASIL BELAJAR SISWA MENGGUNAKAN MODEL PEMBELAJARAN KOOPERATIF TIPE STUDENT TEAMS ACHIEVEMENT DIVISIONS (STAD) PELAJARAN KOMPUTER \& JARINGAN DASAR X TKJ SMK AL ALIF BLORA
}

\author{
Dwi Safitaria $^{1 *}$, Handini Arga Damar Rani ${ }^{2}$, Afis Pratama ${ }^{3}$ \\ Universitas Ivet ${ }^{1,2,3}$ \\ *d.safitaria@gmail.com
}

\begin{abstract}
ABSTRAK
Motivasi dan hasil belajar siswa kelas X TKJ SMK Al Alif Blora tergolong masih rendah karena model pembelajaran yang diterapkan oleh guru masih belum cukup bervariasi sehingga siswa merasa bosan dan hasil belajar pun rendah. Guna mengatasi permasalahan tersebut diperlukan suatu model pembelajaran yang lebih bervariasi yaitu dengan menerapkan model pembelajaran kooperatif tipe Student Teams Achievement Divisions (STAD). Tujuan penelitian ini adalah untuk meningkatkan motivasi dan hasil belajar siswa melalui implementasi model pembelajaran kooperatif tipe STAD pada siswa kelas X TKJ SMK Al-Alif Blora. Penelitian ini merupakan Penelitian Tindakan Kelas (PTK) yang dilaksanakan secara kolaboratif dengan guru mata pelajaran Komputer \& Jaringan Dasar dan ditempuh dalam dua siklus. Setiap siklus terdiri dari empat tahap yaitu perencanaan, pelaksanaan, pengamatan dan refleksi yang dilaksanakan dalam dua kali pertemuan. Adapun yang menjadi subjek penelitian adalah siswa kelas X TKJ SMK Al Alif Blora yang berjumlah 20 siswa. .Hasil penelitian menunjukkan bahwa pembelajaran kooperatif tipe STAD dapat meningkatkan motivasi belajar siswa, persentase motivasi belajar siswa dari siklus I sebesar 58\% meningkat menjadi $74 \%$ pada siklus II dan berada pada rentang skor tinggi. Pembelajaran kooperatif tipe STAD juga dapat meningkatkan hasil belajar siswa, pada siklus I terdapat hanya 3 siswa yang sudah mencapai Kriteria Ketuntasan Minimal (KKM), pada siklus II meningkat sejumlah 75\% siswa telah mencapai KKM.
\end{abstract}

Kata Kunci: Peningkatan Motivasi, Hasil Belajar, Pembelajaran Kooperatif Tipe STAD.

\begin{abstract}
The motivation and learning results of grade X students of SMK Al Alif Blora are still low because the learning model applied by teachers is still not varied enough so that students feel bored and the learning results are low. In order to solve the problem, a more varied learning model is needed by applying a cooperative learning model of Student Teams Achievement Divisions (STAD). The purpose of this research is to improve the motivation and learning outcomes of students through the implementation of stad-type cooperative learning models in grade X students of SMK Al-Alif Blora. This research is a Class Action Research (PTK) conducted collaboratively with teachers of Computer subjects \& Basic Network and carried out in two cycles. Each cycle consists of four stages, namely planning, implementation, observation and reflection conducted in two meetings. The subject of the study was grade X students from SMK Al Alif Blora, which numbered 20 students. The results showed that stad-type cooperative learning can increase student learning motivation, the percentage of student learning motivation from cycle I by $58 \%$ increases to $74 \%$ in cycle II and is in the high score range. Stad-type cooperative learning can also improve student learning outcomes, in cycle I there are only 3 students who have reached the Minimum Completeness Criteria (KKM), in cycle II an increase of $75 \%$ of students reached KKM.
\end{abstract}

Keywords : Increased Motivation, Learning Outcomes, STAD Type Cooperative Learning. 


\section{PENDAHULUAN}

Pendidikan merupakan hal yang penting dalam kehidupan manusia. Setiap manusia mempunyai hak yang sama untuk memperoleh pendidikan dan berharap untuk selalu berkembang dalam pendidikan. Melalui pendidikan seseorang dapat memperoleh pengetahuan yang luas. Pendidikan yang mampu mendukung pembangunan dimasa mendatang adalah pendidikan yang mampu mengembangkan potensi siswa. Sistem pendidikan yang baik akan mampu menghasilkan Sumber Daya Manusia (SDM) yang berkualitas, kompeten, dan profesional dalam bidangnya serta memiliki kemandirian sebagai modal untuk bersaing dengan dunia luar.

Peningkatan motivasi belajar siswa merupakan hal yang paling utama untuk diupayakan. Karena dengan motivasi belajar, siswa terdorong untuk mengikuti pelajaran sehingga konsentrasi siswa terfokus pada pelajaran yang diberikan. Konsentrasi yang terfokus pada pelajaran membuat siswa tidak melakukan kegiatan kegiatan yang tidak berhubungan dengan pelajaran ketika proses belajar mengajar berlangsung. Kondisi kelas menjadi tenang dan proses belajar mengajar menjadi lancar (PKM_AI, 2010). Oleh sebab itu, seorang guru harus memahami pengertian, hakekat, dan sumber-sumber serta berbagai teknik dalam memberikan motivasi kepada siswanya. Kompetensi guru dalam membangkitkan motivasi sangat diperlukan untuk mendorong siswa menyenangkan belajar dan akhirnya mencapai keberhasilan secara maksimal (Gintings, 2010).

Dalam rangka mewujudkan tujuan pembelajaran yang sesuai dengan tujuan pendidikan nasional, guru diharapkan mampu mengembangkan inovasi dan kreativitas. Namun, terdapat hambatan yang umumnya ditemui oleh para guru adalah melakukan variasi ketika kegiatan pembelajaran berlangsung.

Berdasarkan observasi peneliti dan keterangan dari Guru TKJ, Penerapan model pembelajaran di SMK Al Alif Blora masih belum cukup bervariasi, model pembelajaran yang masih diterapkan adalah model pembelajaran konvensional yaitu proses pembelajaran yang terpusat pada guru, dimana guru menjelaskan semua materi sedangkan siswa hanya mencatat apa yang diberikan oleh guru tanpa ada umpan balik. Permasalahan yang sering ditemui oleh guru di dalam kelas $\mathrm{X}$ TKJ dalam pembelajaran Komputer dan Jaringan Dasar yang memiliki keterbatasan dalam fasilitas penunjang pembelajaran. Dimana hanya terdapat beberapa komputer yang bisa digunakan. Contohnya saja dalam materi, mata pelajaran Komputer dan Jaringan Dasar terdiri dari teori dan praktik. Guru biasanya menyajikan materi teori dengan metode ceramah yang biasanya membuat siswa jenuh dan kurang menarik perhatian siswa.

Guna menyelesaikan permasalahan model pembelajaran yang bersifat konvensional, pemahaman siswa yang masih kurang, motivasi dan hasil belajar siswa yang masih rendah, maka diperlukan suatu model pembelajaran yang lebih efektif dan lebih menekankan pada keaktifan belajar siswa pada kegiatan pembelajaran. Salah satu alternatif yang dapat diterapkan adalah melalui penerapan model pembelajaran kooperatif tipe STAD.

Dari permasalahan yang ada dapat diambil rumusan masalah (1) Apakah dengan menggunakan model pembelajaran kooperatif tipe STAD dapat meningkatkan motivasi belajar siswa, (2) Apakah dengan menggunakan model pembelajaran 
kooperatif tipe STAD dapat meningkatkan hasil belajar siswa.

Penelitian ini bertujuan untuk (1) Meningkatan motivasi belajar siswa dalam kegiatan pembelajaran Komputer \& Jaringan Dasar dengan menggunakan model pembelajaran kooperatif tipe STAD, (2) Meningkatan hasil belajar siswa dalam kegiatan pembelajaran Komputer \& Jaringan Dasar dengan menggunakan model pembelajaran kooperatif tipe STAD. Manfaat dari penelitian ini (1) Memberikan motivasi siswa untuk meningkatkan kualitas hasil belajar siswa dalam proses pembelajaran, (2) Menerapkan konsep-konsep pembelajaran, menambah ilmu pengetahuan khususnya di bidang pendidikan.

\section{METODE PENELITIAN}

Metode penelitian yang digunakan peneliti adalah Penelitian Tindakan Kelas (Classroom Action Research). Penelitian Tindakan Kelas (PTK) merupakan suatu bentuk penelitian yang bersifat reflektif dengan melakukan tindakan-tindakan tertentu agar dapat memperbaiki atau meningkatkan praktik-praktik pembelajaran di kelas secara lebih professional (Suyanto, 1997). PTK berupaya meningkatkan dan mengembangkan profesionalisme guru dalam menunaikan tugasnya.

Model Penelitian Tindakan Kelas yang digunakan dalam penelitian ini adalah model yang dikembangkan Kemmis dan Taggart.

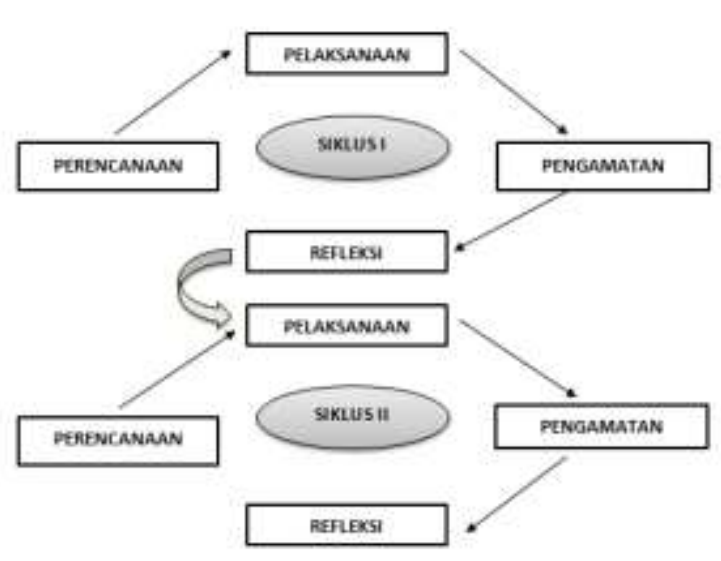

Gambar 1. Model Spiral dari Kemmis dan Mc.Taggart

Pada penelitian ini, dibagi menjadi dua siklus yang dijabarkan sebagai berikut.

(1) Siklus I. Dalam siklus I terdiri dari beberapa tahap yaitu (1) Tahap Perencanaan. Kegiatan yang dilakukan pada tahap ini adalah refleksi awal antara guru dan peneliti terhadap langkah-langkah penerapan model pembelajaran kooperatif tipe STAD. (2) Tahap Pelaksanaan Tindakan. Pada tahap ini peneliti bertindak sebagai observer, mengamati partisipasi siswa pada kegiatan pembelajaran di kelas, sedangkan guru melaksanakan desain pembelajaran seperti yang telah direncanakan. Namun, pada pelaksanaannya bersifat fleksibel, dapat berubah sesuai kondisi. (3) Tahap Observasi I. Observasi dilakukan selama berlangsungnya pelaksanaan proses pembelajaran di kelas. Hal-hal yang perlu diobservasi meliputi : observasi motivasi belajar siswa selama proses pembelajaran secara individu maupun kelompok. Dalam tahap observasi ini guru bisa dibantu oleh pengamat. (4) Tahap Refleksi. Kegiatan refleksi dilakukan dengan cara diskusi antara guru dan peneliti untuk mengevaluasi hasil tindakan yang telah dilaksanakan, hambatan-hambatan yang muncul, dan melakukan penilaian 
terhadap hasil tindakan. Hasil refleksi digunakan untuk memperbaiki kegiatan pada siklus selanjutnya. Apabila tindakan pada siklus I belum menunjukkan hasil yang optimal, maka perlu dilakukan langkah perbaikan pada siklus selanjutnya.

(2) Siklus II. Dalam siklus II juga dilakukan beberapa tahap seperti siklus I yaitu (1) Tahap Revisi Perencanaan. Pada tahap revisi perencanaan dilakukan penyusunan rencana baru untuk memperbaiki hasil refleksi pada siklus I. (2) Tahap Pelaksanaan Tindakan. Tahap ini hampir sama dengan tahap pelaksanaan tindakan pada siklus I, guru melaksanakan desain pembelajaran sesuai yang direncanakan, materi yang diajarkan merupakan materi lanjutan siklus I. (3) Tahap Observasi II. Melakukan observasi selama proses pembelajaran di kelas, hal-hal yang diobservasi sama dengan siklus I. (4) Tahap Refleksi Siklus II. Refleksi pada siklus II dilakukan untuk mengetahui perbedaan hasil siklus I dengan siklus II. Apabila pada siklus ini telah terjadi peningkatan motivasi dan hasil belajar siswa, maka siklus tidak perlu diulang kembali.

\section{Teknik Pengumpulan Data}

Dalam pengumpulan data peneliti menggunakan beberapa teknik peneltian, yaitu : metode tes, observasi dan dokumentasi. Tes adalah serentetan pertanyaan atau latihan yang digunakan untuk mengukur tingkat kognitif yakni, pengetahuan, pemahaman dan aplikasi yang dimiliki oleh individu atau kelompok. Metode observasi atau pengamatan adalah kegiatan keseharian manusia dengan menggunakan pancaindera mata dan di bantu dengan pancaindera yang lainnya dan dokumentasi digunakan sebagai penguat data yang diperoleh selama kegiatan observasi berlangsung.

\section{Instrumen Penelitian}

Instrumen penelitian yang digunakan peneliti meliputi tes dan observasi. Tes hasil belajar dilakukan untuk mengetahui kualitas hasil belajar. Untuk mengetahui dan mengukur pemahaman, kemampuan serta aplikasi seorang siswa, maka pada penelitian ini akan dilakukan post tes, yang terdiri dari tes kelompok dan tes individu. Observasi digunakan untuk mengamati siswa dalam pelaksanaan model pembelajaran kooperatif tipe STAD dalam proses pembelajaran.

\section{Teknik Analisis Data}

Analisis data dilakukan setiap siklus berakhir. Data penelitian yang terdiri dari hasil observasi dan tes belajar. Data yang diperoleh akan diolah dan dianalisis secara deskriptif kualitatif dan deskriptif kuantitatif yaitu : Deskriptif kualitatif digunakan untuk menganalisis hasil data observasi. Deskriptif kuantitatif digunakan untuk menganalisis hasil tes belajar siswa.

Untuk mengetahui prosentase nilai siswa yang tuntas per siklus, dianalisis dengan menggunakan rumus sebagai berikut :

$P=\frac{f}{N} X 100 \%$

Keterangan :

$P \quad=$ Prosentase yang akan dicari

$f \quad=$ Jumlah siswa yang tuntas

$N \quad=$ Jumlah seluruh siswa

Rumus untuk menghitung persentase hasil observasi motivasi belajar siswa yaitu :

$\%$ motivasi belajar $=$ Skor total yang diperoleh $\times 100 \%$ Skor maksimal

\section{HASIL DAN PEMBAHASAN}

Model penelitian ini menggunakan model yang dikembangkan Kemmis dan Taggart. Penelitian ini dilaksanakan di SMK Al Alif pada siswa kelas $\mathrm{X}$ TKJ yang 
berjumlah 20 siswa terdiri dari 5 siswa putra dan 15 siswa putri. Penelitian ini dilaksanakan dalam dua siklus. Tiap siklus terdiri dari empat tahap, yaitu Perencanaan Tindakan, Pelaksanaan Tindakan, Observai dan Refleksi.

Hasil dari penelitian menunjukkan bahwa penerapan model pembelajaran kooperatif tipe STAD dapat meningkatkan motivasi dan hasil belajar siswa pada mata pelajaran Komputer dan Jaringan Dasar kelas X TKJ di SMK Al Alif Blora yang dapat dilihat pada gambar grafik sebagai berikut :

(1) Peningkatan Motivasi Belajar Siswa melalui Implementasi Pembelajaran Kooperatif Tipe STAD.

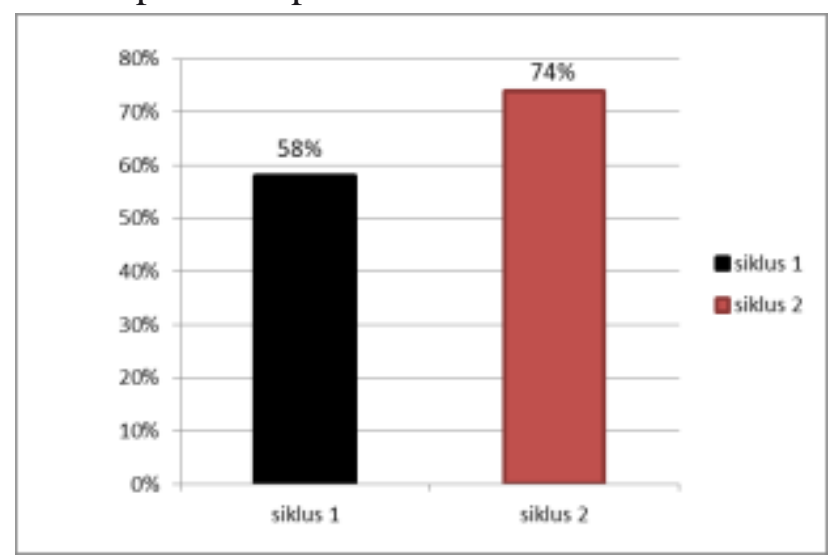

Gambar 2. Grafik Motivasi Belajar Siswa Siklus I dan Siklus II

Gambar grafik di atas menunjukkan terjadi peningkatan motivasi belajar siswa dari siklus I ke siklus II. Indikator keberhasilan pada bab 3 yang menyebutkan apabila skor motivasi belajar siswa mengalami peningkatan dari satu siklus ke siklus berikutnya dan mencapai kategori tinggi yaitu $65 \%-84 \%$ telah tercapai yaitu motivasi belajar siswa dari siklus I sebesar 58\% mengalami kenaikan pada siklus II yaitu mencapai $74 \%$ pada rentang skor tinggi. Hal ini menunjukkan telah terjadi peningkatan motivasi belajar siswa dari siklus I ke siklus II sebesar 16\%.

(2) Peningkatan Hasil Belajar Siswa melalui Implementasi Pembelajaran Kooperatif Tipe STAD

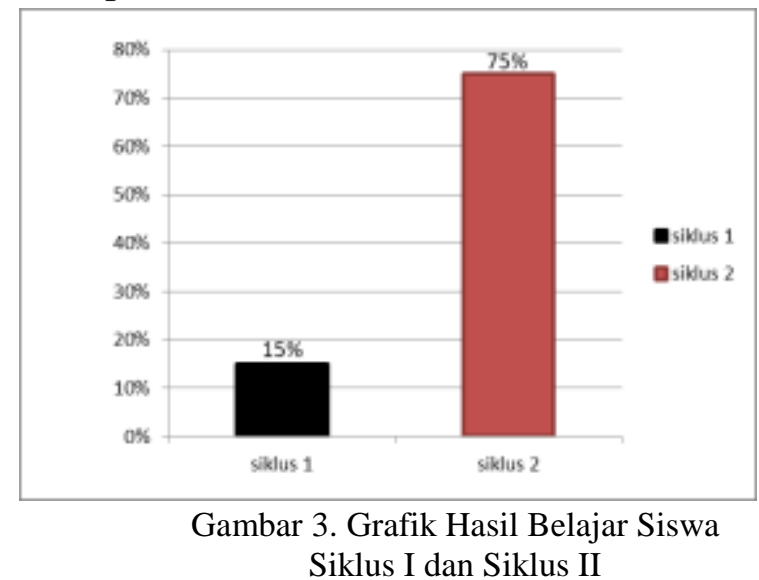

Pada gambar grafik di atas nampak bahwa hasil post-test pada siklus I sejumlah $15 \%$ atau 3 siswa sudah mencapai KKM, namun sebanyak $85 \%$ siswa masih belum mencapai KKM dengan nilai di bawah 76 . Pada siklus II, hasil post-test seluruh siswa mengalami peningkatan yang baik yaitu $75 \%$ siswa telah mampu mencapai KKM dengan nilai lebih dari 76 dan sebanyak 25\% siswa yang masih belum mencapai KKM. Rata-rata kelas pada siklus I ke siklus II juga mengalami peningkatan sebesar 22,25 poin dari 55,25 menjadi 80,5 meningkat sebesar $60 \%$ dibanding siklus I. Siswa secara individual juga telah mengalami peningkatan nilai dari siklus I ke siklus II.

\section{PENUTUP}

Kesimpulan yang dapat diambil dari penelitian tindakan kelas menggunakan model pembelajaran kooperatif tipe STAD pelajaran komputer dan jaringan dasar kelas X TKJ di SMK Al Alif Blora adalah : (1) Pembelajaran kooperatif tipe STAD dapat meningkatkan motivasi belajar siswa. Hal ini ditunjukkan peningkatan persentase motivasi belajar siswa pada siklus I sebesar $58 \%$ dan pada siklus II sebesar $74 \%$. 
Berdasarkan kategori skor, rentang skor $74 \%$ tergolong skor kategori tinggi. (2) Pembelajaran kooperatif tipe STAD dapat meningkatkan hasil belajar siswa. Pada siklus I hanya sebanyak $15 \%$ siswa yang mencapai KKM, namun pada siklus II telah terjadi peningkatan yaitu $75 \%$ siswa telah mencapai KKM.

Saran yang dapat diambil dari penelitian ini adalah guru dapat mengembangkan model pembelajaran yang lebih variatif salah satunya menggunakan model pembelajaran kooperatif tipe STAD dan Siswa diharapkan dapat mengemukakan pendapat agar pembelajaran dapat dilaksanakan dari dua arah yaitu guru dan siswa, serta mampu melaksanakan diskusi kelas dengan baik dan mampu bekerjasama dengan teman di dalam proses belajar mengajar.

\section{DAFTAR PUSTAKA}

Gintings, A. (2010). Esensi Praktis; Belajar Dan Pembelajaran. Humaniora.

Program Kreatifitas Mahasiswa. (2010). Hasil Evaluasi. Direktorat Penelitian dan Pengabdian Kepada Masyarakat.

Risdiawati, Y. (2012). Implementasi Model Pembelajaran Kooperatif Tipe Student Teams Achievement Divisions ( Stad) Untuk Meningkatkan Motivasi Dan Hasil Belajar Akuntansi Siswa Kelas Xi Ips 4 Sma Negeri 1 Imogiri Tahun Ajaran 2011/2012. -, 214.

Suyanto. (1997). Pedoman Pelaksanaan

Penelitian Tindakan Kelas (Jakarta).

Departemen Pendidikan dan

Kebudayaan. 